DOI: 10.34015/2523-4552.2020.4.13

УДК 346.7

Kогут М. Г.,

старший викладач кафедри

теорії та історії держави і права

юридичного факультету

Державного вищого навчального

закладу «Ужгородський національний

університет»

ORCID: 0000-0001-7885-7416

\title{
ШЛЯХИ ВДОСКОНАЛЕННЯ ПРАВОВОГО РЕГУЛЮВАННЯ НЕПРЯМИХ ПОДАТКІВ
}

Досліджується проблематика недоліків, які притаманні непрямим податкам та шляхи їх вдосконалення та подолання, в тому числі на прикладі іноземних країн.

Ключові слова: непрямі податки; ПДВ; акциз; адміністрування податків.

Исследуется проблематика недостатков, которые присущи косвенным налогам и пути их совершенствования и преодоления, в том числе на примере зарубежных стран.

Ключевые слова: косвенные налоги; НДС; акциз; администрирование налогов.

Постановка проблеми. Фінансова криза змусила країни дуже уважно поглянути на склад своїх податкових надходжень. Уряди також сперечалися щодо найкращого способу введення жорстких заходів. Зокрема, чи слід знижувати ставки податків, пов'язаних із споживанням, щоб допомогти платникам податків за рахунок збільшення наявного доходу або збільшити для отримання вкрай необхідних податкових надходжень. Ще однією з причин, чому уряди мають сильну прихильність щодо непрямих податків, $\epsilon$ те, що вони базуються на споживанні i, отже, $\epsilon$ стабільним джерелом доходів.

Аналіз останніх досліджень і публікацій. Важливі питання досліджуваної проблеми розглядалися в багатьох працях вітчизняних учених, зокрема А. С. Абрамова, В. С. Альошкін., В. Л. Андрущенко, О.М.Бандурка, П. М. Боровик, В. В. Буряковський, П. Т. Гега, Я. В. Греца, О. Д. Данилов, В. А. Дедекаєв, Л. М. Доля, О. С. Задорожний, А. І. Крисоватий, В. О. Ладиженська, І. О. Лютий, К. А. Матвійчук, М. М. Мельник, О. І. Оксенюк, Т. В. Паєнтко, В.Ф. Роль, О. М. Скибіцький А. В. Скрипник, А. М. Соколовська. Водночас, не применшуючи значення цих та багатьох інших досліджень, зазначимо, що у зв`язку з тим, що обрана тематика безпосередньо залежить від етапу розвитку суспільних відносин, її дослідження залишається актуальним.

Постановка завдання. Можливість збирати податки $є$ основною для спроможності країни фінансувати соціальні послуги, такі як охорона 
здоров'я та освіта, важлива інфраструктура, така як електроенергія та дороги, та інші суспільні блага. Враховуючи величезні потреби бідних країн, цей низький рівень збору податків ставить під загрозу економічний розвиток.

Податок може бути визначений як грошовий тягар, покладений на фізичних осіб або власників майна для підтримки уряду, платіж, який вимагає законодавча влада. Податок не $\epsilon$ добровільним платежем чи пожертвою, а примусовим внеском, що вимагається відповідно до законодавства. Однак, основним завданням уряду будь-якої країни є формування податкової політики таким чином, щоб «тягар» який безпосередньо чи опосередковано лягає на плечі платників був посильним не лише для осіб з високим рівнем доходу, але й для бідного населення. Завданням даного дослідження $\epsilon$, саме, пошук тих форм і методів удосконалення правового регулювання, які дадуть змогу звести негативний вплив непрямих податків і сформувати сприятливий економічний клімат в країні. Що, в свою чергу, не тільки підвищить рівень інвестицій, але й покращить середньостатистичний показник рівня доходів на душу населення.

Виклад основного матеріалу. Незважаючи на те, що уряд намагається краще узгодити політику оподаткування прибутку підприємств із сучасною діловою діяльністю, щоб отримати більше доходів, він також зосереджуються на непрямих податках. Якщо говорити про міжнародну спільноту, то, наприклад, за оцінками Європейської комісії, 28,2 країничлена Європейського Союзу в 2013 році не зібрали 15,2\% податку на додану вартість (ПДВ), податковий розрив склав 170 млрд. євро. Проблематика непрямих податків включаючи ПДВ, податок на товари та послуги (GST), митні та акцизні збори - далеко не нова.

Однак вона зростає, оскільки непрямі податки, які збираються від імені уряду тими, хто продає товари та послуги, забезпечує зростаючу частку державних доходів. Податкові та митні адміністрації посилюють зусилля щодо дотримання та забезпечення порядку стягнення непрямого податку, у тому числі для цифрових продуктів та послуг. Виклики та ризик суперечок у непрямому податковому просторі різноманітні, включаючи складне законодавство та різні зобов'язання щодо дотримання законодавства від країни до країни та в залежності від зміни бізнес-моделі.

Податки на споживання швидко поширилися по всьому світу. Винайдений у Німеччині та вперше запроваджений у Франції в 1954 році, сьогодні ПДВ справляється в 167 країнах від Албанії до Зімбабве. США - єдиний член ОЕСР, який не має федерального податку з продажу, однак 45 із 50 штатів та тисячі місцевих юрисдикцій вводять податки з продажу, які, як правило, збираються роздрібними продавцями та постачальниками послуг і перераховуються державі.

Однак різниця між об єктами, що підлягають оподаткуванню та що не підлягають оподаткуванню, не завжди може бути чіткою, і порядок їх оподаткування може відрізнятися залежно від країни. Прикладами $\epsilon$ складні багатосторонні домовленості, такі як програми лояльності та багатосторонні гарантії. Багатоюри- 
сдикційні та цифрові операції лише збільшують складність адміністрування непрямих податків (або податків на споживання). Припущення, що ПДВ, наприклад, $є$ простим податком - невірне, бо не враховує складності реальних операцій.

Поліпшення рівня збору непрямих податків стало метою урядів повсюдно. Зрештою, зниження рівня надходжень від непрямих податків може загрожувати дієздатності держави стосовно сплати рахунків, або продовження виплат відсотків за позиками, або виплати заробітних плат .

У звіті EY щодо управління конфліктами щодо непрямих податків у 2015 році було виявлено, що 56 країн (із 82) здійснюють обмін інформацією про ПДВ лише з різними відомствами національних органів влади, тоді як лише 51 країна обмінюється інформацією про ПДВ / податки на товари та послуги 3 іншими країнами, намагаючись покращити відповідність і визначити ризик [1, p. 4].

Один із найяскравіших прикладів запобігання ухиленню від сплати ПДВ та сплати інших податків із даної групи було розпочато в Португалії. Податковий орган створив центральну базу даних моніторингу ПДВ, підключену до систем усіх компаній, що забезпечують продажі на суму понад 100000 євро на рік. Система швидко виявила 128000 компаній 3 порушеннями, а загальний дохід від податків у 2013 р. Зріс на $13 \%$. У ресторанному секторі ПДВ зріс на 140\% у період 2011-2013 pр. Подібні системні зв'язки в режимі реального часу для боротьби 3 шахрайством розгорнуті в Бразилії та Китаї. Наприклад, в останній країні постачальники зобов'язані вводити дані про транзакції в систему програмного забезпечення Jinshui або Golden Tax, щоб виставити рахунокфактуру з ПДВ. Раніше у Китаю виникала проблема 3 шахрайством 3 ПДВ, однак, на даний час, вони впровадили програмну систему Golden Tax і ця ситуація значно покращилася [2].

Але навіть коли уряди різних країн зосереджуються на вирішенні давніх проблем у сфері непрямого оподаткування, цифрова економіка породила купу нових, особливо транскордонних викликів. I, як показує практика і динаміка розвитку світової економіки, значна частина майбутніх конфліктів виникне внаслідок цифрової ери в економіки.

Роздрібна торгівля в мережі «Інтернет» $є$ одним із основних «тестувальників» якості адміністрування непрямих податків. Наприклад, коли інтернет-продавець не включає в ціну товару суму ПДВ, то покупець, відповідно, не сплачує його. Таким чином продавець свідомо, а покупець несвідомо (в більшості випадків) ухиляються від сплати ПДВ. Такі дії, в результаті, завдають великого удару по дохідних статтях державного бюджету. Тому, законодавець спільно з урядом повинні працювати над створенням консенсусу щодо того, як вирішити проблемні питання непрямого оподаткування, яке все частіше стає серцем транскордонної економіки.

Також, ця тематика стає дедалі актуальнішою, оскільки країни більше покладаються на непрямі податки та зменшують свою залежність від прямих податків. Питання полягає в тому, чи координується ця увага таким чином, щоб запобігти 
перенапруженню транскордонних служб зі сторони непрямого оподаткування. Це, мабуть, одне з наступних серйозних питань, що постануть як щодо непрямого оподаткування, так і щодо міжнародного податкового сектора в усьому світі.

Важливо розуміти той факт, що податкова політика в Україні повинна сприяти насамперед збільшенню обсягів нагромадження, створенню умов, що полегшують підприємствам відновлення основного капіталу 3 одного боку, та їх конкурентоспроможність на міжнародній арені, 3 іншого.

Податки - найбільш адекватний у свободі господарської діяльності метод відносин держави як з підприємствами, так і 3 населенням, найдемократичніший спосіб економічного регулювання. Оновлена податкова система повинна враховувати принципові зміни, що відбуваються в країні. Отже, необхідно забезпечити існування розгалуженої податкову службу з метою контролю і своєчасної сплати податків.

Варто також забезпечити гнучкість податкової системи, пристосувати її до зовнішньої і внутрішньої економічної кон'юнктури. Необхідно звести до мінімуму негативний вплив на економіку країни тіньового бізнесу. Аналіз ситуації, що склалася, свідчить, що тіньова діяльність завдає збитків однаковою мірою як державі, так і кожному підприємцеві, що працює легально. Тіньова економіка небезпечна ще й тим, що активно залучає до своєї сфери нових i нових суб'єктів підприємницької діяльності.

Основне завдання податкової адміністрації - це систематично відпрацьовувати найзначніші факти ухиляння від сплати податків, попереджати масові порушення податкового законодавства. Таким чином, поняття податкової реформи охоплює не тільки зміну законодавства, що регулює розміри і процес збирання податків, а й модернізацію податкової служби, приведення її у відповідність 3 існуючими ринковими нововведеннями, що могло б на достатньому рівні забезпечувати доходи в бюджет.

На разі, ми бачимо, що податкові реформи відбуваються. Введення системи електронного адміністрування ПДВ - це уже «крок на зустріч» європейській податковій системі. Однак, зараз на органи податкового контролю покладається не лише обов'язок остаточно і всеціло ввести таку систему, але й підтримувати її належне існування. Зокрема, провести роз'яснювальну роботу 3 тими, хто до цих пір стикається 3 проблемами в даній сфері в першу чергу - з платниками податку.

Власне, і сама процедура списання коштів з рахунків платника в даному випадку не регламентована належним чином, адже законодавство не передбачає внесення змін до Закону України «Про платіжні системи та переказ коштів в Україні», норми якого регулюють засади функціонування платіжних систем i систем розрахунків в Україні, закріплюючи правові механізми руху коштів в межах даних систем. Таким чином, для перерахування коштів 3 рахунків платника податків, контролюючий орган не видає жодного акту, який впливав би на виникнення, зміну або припинення обов'язків платника податків, тобто акту, який би підлягав оскарженню в адміністративному чи судовому порядку. 
Також без відповіді залишається питання про те, чи можливий зворотній процес: погашення заборгованості платника з інших податків за рахунок коштів в системі електронного адміністрування ПДВ, адже, наприклад, змін до статті 95 ПК України докорінно не вносились. Дана стаття передбачає реалізацію майна платника в режимі податкової застави і при цьому оперує поняттям «стягнення з рахунків платника у банку», тим самим не розмежовуючи рахунки платника в системі електронного адміністрування ПДВ від інших [3].

I таких «нюансів» в даній ситуації ще $є$ багато, а, отже, для удосконалення правового регулювання непрямих податків ще $є$ багато можливостей. Однозначно, те, що вже відбулось має позитивні наслідки. Введена система електронного адміністрування мінімізує прояви «податкових ям». Але це в ідеалі. А на разі, ми бачимо, що $\epsilon$ ще багато упущень, які лише сприятимуть тіньовим схемам при сплаті ПДВ.

Що стосується акцизного податку, то тут, в першу чергу, потрібно звертатись до практики країн $€ C$, адже в наведених вище фактах прослідковувались можливі варіанти реформування даного виду податку для максимально ефективного його застосування 3 метою наповнення державного бюджету. Законодавці повинні зрозуміти єдине правило: акциз - специфічний податок і його важливе не його сприйняття населенням, а його ефективне застосування законодавцем.

Варто зазначити, що акцизний податок формує значну частину доходів зведеного бюджету України. В той же час, навіть після введення в дію Податкового кодексу України та внесення до нього ряду змін, пов'язаних з оподаткуванням підакцизних товарів, механізм справляння акцизного податку має цілий ряд недоліків, пов'язаних зі зростанням фіскальних властивостей цієї податкової форми та зменшенням ï̈ регулюючого впливу на виробництво i обіг підакцизних товарів. 3 цієї причини сучасний порядок вітчизняного акцизного оподаткування потребує суттєвого вдосконалення, завданням якого повинно бути 3 одного боку унеможливлення тіньового обігу підакцизних товарів, а 3 іншого забезпечення виконання цим платежем не лише фіскальних завдань, але й регулюючих функцій. При цьому, основними кроками на шляху вдосконалення механізму справляння акцизного податку повинні бути:

- забезпечення стабільності ставок цього платежу протягом тривалого періоду (як мінімум - 3-5 років);

- запровадження більш захищених від підробок акцизних марок на алкогольні і тютюнові вироби;

- розширення прав та підвищення рівня відповідальності працівників податкових та митних органів, задіяних у сфері контролю за виробництвом і обігом підакцизних товарів;

- суттєве збільшення переліку підакцизних товарів за рахунок ювелірних виробів, дорогих імпортних автомобілів та інших предметів розкоші [4, с. 103-104].

Необхідність практичної реалізації напрямів реформування механізмів акцизного оподаткування доводиться тим, що така реалізація призведе до формування прозорого і стабільного правового поля діяльності 
платників цього податку, сприятиме становленню справедливого конкурентного середовища та, одночасно, спричинить зростання обсягів надходжень саме від цього виду непрямих податків до державного бюджету.

Сьогодні в нашій державі створено власну податкову систему, яка не $\epsilon$ результатом копіюванням досвіду інших країн. Процес імплементації норм міжнародного податкового права та податкового права ЄС до національного законодавства України проявився в низці правових актів останнього часу. Податкові норми кодифіковано в єдиний правовий акт, створено систему контролюючих органів із сучасною організаційною структурою. Однак, така податкова система має ще багато недоліків, які потребують виявлення і виправлення. Наша податкова система $\epsilon$ ще достатньо молодою і потребує значної уваги. Однак ті кроки до її удосконалення, які вже тепер здійснюються свідчать про наявність євро інтеграційних процесів у даній сфері.
Висновки. Отже, якщо говорити про правове регулювання непрямого оподаткування в Україні, то можна дійти до висновку, що існує ще багато недоліків у цій сфері. Однак, українське законодавство міняється, намагаючись гармонізуватись 3 законодавством Європейського Союзу. Україна робить впевнені кроки на світовому ринку, підтвердженням чого $є$ підписання угоди про асоціацію з ЄС. I хай ситуація в країні $€$ нестабільною, однак саме чітка та впевнена політика в провідних сферах державного життя (однією з яких являється сфера податків) допоможе подолати нестабільність, політичну кризу та проблеми фінансового сектору. Податки - це один із видів спілкування держави $з$ їі громадянами. Тому законодавець повинен пам'ятати, що для підтримання добробуту суспільства, таке «спілкування» повинне приносити заспокоєння і впевненість для громадян, формуючи стабільну та процвітаючу державу.

\section{Список використаних джерел}

1. Managing indirect tax controversy. Dealing with audits and disputes. Executive summary. EY Global. 2015. URL: https://cdn.ey.com/echannel/gl/en/services/tax/VAT-GST-and-other-sales-taxes/indirect-tax-controversy/ey-TL-exec-summary-2015.pdf (дата звернення: 20.10.2020).

2. Why indirect taxes are the next frontier in controversy. EY Global. 2019. URL: https://www.ey.com/en_gl/tax/why-indirect-taxes-are-the-next-frontier-in-controversy (дата звернення: 20.10.2020).

3. Макарчук Р. Проблеми впровадження системи електронного адміністрування податку на додану вартість. Взгляд юриста. Юридический блог компании Јигітех. 2014. URL: http://jurblog.com.ua/2014/09/problemi-vprovadzhennya-sistemielektronnogo-administruvannya-podatku-na-dodanu-vartist/ (дата звернення: 20.10.2020).

4. Боровик П. М., Ладиженська В. О. Проблеми акцизногооподаткування в Україні. Економічний вісник Донбасу. № 3 (25). 2011. С. 103-107.

\section{References}

Borovik, P. M., Ladizhenska, V. O. (2011). Problemi akciznogoopodatkuvannya v Ukrayini. Ekonomichnij visnik Donbasu, 3 (25), 103-107. 
M. Kohut, Senior Lecturer of the department theory and history of state and law Faculty of Law "Uzhgorod National University"

e-mail: kogutmarina8@gmail.com; ORCID:0000-0001-7885-7416

\section{Ways to improve the legal regulation of indirect taxes}

The problems of shortcomings inherent in indirect taxes and ways to improve and overcome them, including the example of foreign countries, are studied. The financial crisis has forced countries to look very closely at the composition of their tax revenues. Governments have also debated the best way to impose tough measures. In particular, should consumption-related tax rates be lowered to help taxpayers increase their disposable income or increase it to generate much-needed tax revenue. Another reason why governments have a strong commitment to indirect taxes is that they are consumption-based and therefore a stable source of revenue.

The ability to collect taxes is central to a country's ability to fund social services such as health and education, important infrastructure such as electricity and roads, and other public goods. Given the huge needs of poor countries, this low level of tax collection threatens economic development.

The main task of the government of any country is to formulate tax policy in such a way that the "burden" that directly or indirectly falls on the shoulders of taxpayers is feasible not only for people with high incomes, but also for the poor. The task of this study is to find those forms and methods of improving legal regulation that will reduce the negative impact of indirect taxes and create a favorable economic climate in the country. Which, in turn, will not only increase the level of investment, but also improve the average level of per capita income.

If we talk about the legal regulation of indirect taxation in Ukraine, we can conclude that there are still many shortcomings in this area. However, Ukrainian legislation is changing in an attempt to harmonize with European Union legislation. Ukraine is taking confident steps on the world market, as evidenced by the signing of an association agreement with the EU. And although the situation in the country is unstable, it is a clear and confident policy in the leading spheres of public life (one of which is the sphere of taxes) will help to overcome instability, political crisis and the problems of the financial sector. Taxes are one of the types of communication between the state and its citizens. Therefore, the legislator must remember that in order to maintain the welfare of society, such "communication" must bring peace and confidence to citizens, forming a stable and prosperous state.

Keywords: indirect taxes; VAT; excise duty; tax administration. 